\title{
INFLUENCE OF BUCKLING FORMS INTERACTION ON STIFFENED PLATE BEARING CAPACITY
}

\author{
Gaik A. Manuylov, Sergey B. Kosytsyn, Irina E. Grudtsyna \\ Russian University of Transport (MIIT), Moscow, RUSSIA
}

\begin{abstract}
The work is devoted to studying the influence of initial geometric imperfections on a value of the peak load for the compressed stiffened plate with the two-fold buckling load. The finite-element set MSC PATRAN NASTRAN was used for solving the set tasks. When modelling the stiffened plate, flat four-unit elements were used. Geometric non-linearity was assumed for calculations. The plate material was regarded as perfectly elastic. Buckling forces of stiffened plate at the two-fold buckling load were calculated (simultaneous buckling failure on the form of the plate total bending and on the local form of wave formation in stiffened ribs). Equilibrium state curves, peak load decline curves depending on initial imperfection values and the bifurcation surface were plotted.
\end{abstract}

Key words stability, stiffened plate, bifurcation, initial geometric imperfections, buckling force

\section{ВЛИЯНИЕ ВЗАИМОДЕЙСТВИЯ ФОРМ ВЫПУЧИВАНИЯ НА НЕСУЩУЮ СПОСОБНОСТЬ ПОДКРЕПЛЕННОЙ ПЛАСТИНЫ}

\author{
Г.А. Мануйлов, С.Б. Косицын, И.Е. Грудцына \\ Российский университет транспорта (РУТ (МИИТ)), г. Москва, РОССИЯ
}

\begin{abstract}
Аннотация: В работе исследовано влияния начальных геометрических несовершенств на величину максимальной нагрузки для сжатой подкрепленной пластины с двукратной критической нагрузкой. Для решения поставленных задач использовался конечноэлементный комплекс MSC PATRAN - NASTRAN. При моделировании подкрепленной пластины использованы плоские четырехузловые элементы. Расчеты выполнялись с учетом геометрической нелинейности. Материал пластины считался абсолютно упругим. Рассчитаны критические силы подкрепленной пластины при двукратной критической нагрузке (одновременная потеря устойчивости по форме общего изгиба пластины и по локальной форме волнообразования в подкрепляющих ребрах). Построены кривые равновесных состояний, кривые падения максимальных нагрузок в зависимости от величины начальных несовершенств, а также бифуркационная поверхность.
\end{abstract}

Ключевые слова: устойчивость, подкрепленная пластина, бифуркация, начальные геометрические несовершенства, критическая сила

\section{INTRODUCTION}

Stiffened plates are quite a widespread element of construction, machine-building, aviation and ship structures. Interaction of forms of buckling failure is an important factor at evaluation of post-critical equilibrium of thin-walled stiffened plates. Such interaction is manifested either in form of interinfluence of the plate total deflection as Eulerian rod and the local buckling failure of the lining (wave formation in the plate), or as interinfluence of the abovementioned total deflection and wave formation at buckling failure of compressed ribs. Especially interesting in buckling problems are stiffened plates with two-fold buckling loads corresponding to the simultaneous buckling failure both on the shape of total bending of the plate and on the form of local bending in form of wave formation of ribs for plates possessing open profile rib stiffeners; this 
interinfluence considerably decreases the buckling load A. Van Der Neut, M. Tvergaard, W. Fok, J. Rhodes, A. Walker, G. Hunt, M.T. Thompson, A.I. Manevich, et al. devoted their efforts to studying of the effect of forms interaction whereat bearing capacity of stiffened plates and shells would decline. In his doctor's thesis [19] A.I. Manevich described interaction effects of buckling failure forms for thin-walled stiffened structures using the non-linear stability approach. His results occurred to be of great interest: the wave formation of ribs decreased the buckling load of stiffened plates from $40 \%$ to $60 \%$; this paper also demonstrates necessity to use the plate-like pattern of a rib. In this paper, the authors explored the phenomenon of influence of non-linear interinfluence of forms and initial geometrical imperfections on the buckling load. To plot equilibrium state lines in vicinity of the twofold semi-symmetric critical point, conceptions of the modern bifurcation theory and catastrophe theory were used. Earlier, on the base of V.Tvergaard's solution for the wide integrally stiffened plate under compression, G. Hunt plotted a bifurcation surface for a homeoclinal point of hyperbolic umbilic bifurcation. This surface is determined with the three parameters (the load parameter, and two imperfections parameters, that is, relative amplitudes of buckling failure partial forms). The mentioned two-fold semisymmetric critical point (homeoclinal point of bifurcation) is realized when the critical force for the general form of buckling failure as of Eulerian rod is near or coincident in its value to the buckling load of wave formation local point [2]. It is related to the development direction of the stiffened plate general deflection toward ribs. At such deflection, a deflecting moment is generated which additionally loads the plate (shell) and unloads the ribs. However, if the general deflection develops in opposite direction, ribs under compression will be additionally loaded, while the plate (shell), on the contrary, will be unloaded in terms of compression. In the case of total or nearcoincidence of buckling loads of the buckling and wave formation general form in the ribs, the near-critical equilibriums shall be described by another semi-symmetric two-fold bifurcation point, that is, by the anticlinal one [2] corresponding to the elliptical umbilic catastrophe. In the paper [2] G. Hunt, while analyzing the paper [1], pointed out the possibility of occurring of the bifurcation anticlinal point, if the general deflection causes additional compression of ribs. We note here that studying of the stiffened plate behaviour near an unstable two-fold bifurcation point was dictated by the consideration that it was there where the ultimate sensitivity to initial imperfections was observed for majority of elastic systems.

\section{PROBLEM FORMULATION}

The stability problem for the stiffened plate was solved by the finite elements' method in geometrically non-linear formulation. The plate had the following geometric parameters:

- Plate length: $86 \mathrm{~cm}$,

- Plate width: $36 \mathrm{~cm}$,

- $\delta=0.155 \mathrm{~cm}, \mathrm{e}=0.342 \mathrm{~cm}$,

- $\mathrm{J}=3.136 \mathrm{~cm}^{4}$,

- $\mathrm{b}_{\mathrm{p}}=0.1 \mathrm{~cm}, \mathrm{~h}_{\mathrm{p}}=1.2 \mathrm{~cm}$,

where $\delta$ - plate thickness, e - position of the cross section main central axis, $\mathrm{J}$ - moment of inertia in respect to the main central axis, $b_{p}-$ rib thickness, $h_{p}-$ rib height.

The accepted boundary conditions: hinge support along short sides, with free longitudinal edges. The stiffened plate cross section is shown in figure 1 . The finite-element model is built within the MSC PATRAN - NASTRAN calculation complex, with use of finite elements of shell type (4002 elements) (figure 2). The material was regarded perfectly elastic $\left(\mathrm{E}=2 \cdot 10^{6} \mathrm{~kg} / \mathrm{cm}^{2}, \mu=0.3\right)$.

The compressing load (four forces) has been applied in points of intersection of ribs symmetry axes and the cross section main central axis. 


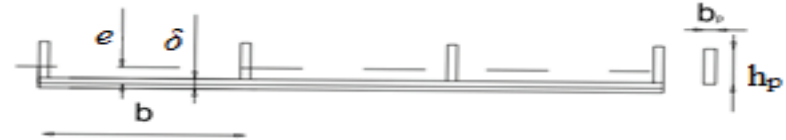

Figure 1. The plate cross section.

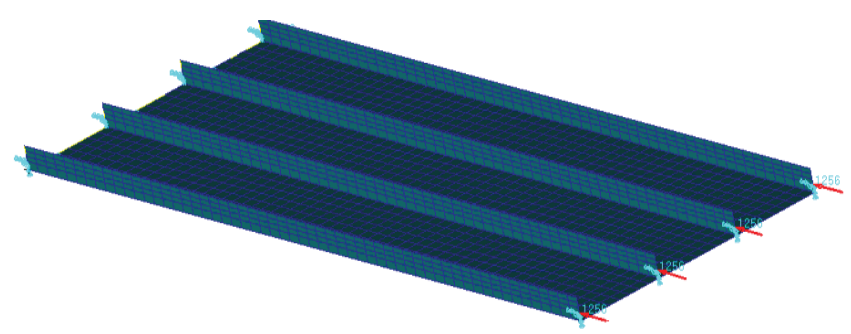

Figure 2. Finite-element model.

\section{STUDYING OF POST-CRITICAL EQUI- LIBRIUM OF A STIFFENED PLATE WITH TWO-FOLD BUCKLING LOAD}

This paper is devoted to studying of the problem of interaction of buckling failure forms between the shape of the plate general bending and the local shape of ribs wave formation. In practice, such a situation can occur, e.g., in bridges with continuous carriageways in form of a compressed stiffened plate. The linear computation of stability showed that the buckling load corresponding to the shape of plate buckling in form of Eulerian rod $\left(\mathrm{P}_{\text {эл }}=7708 \mathrm{~kg}\right)$ is sufficiently close to the buckling load corresponding to the form of wave formation of ribs $\left(\mathrm{P}_{\text {в.p. }}=7818 \mathrm{~kg}\right)$. The under-critical and initial post-critical equilibrium was studied in the geometrically non-linear formulation; the following results were obtained:

- as the compression load increases, the plate total deflection would develop downwards (i.e. in such a way that the ribs occur on the plate concave side and would receive additional compression).

- buckling failure occurs at the maximum buckling load Pcr $=6797 \mathrm{~kg}$ in the wave formation symmetric bifurcation point in the two middle ribs (the point of sharp inflection to curves of general deflection development. This load is $11.81 \%$ less than the buckling load obtained from the linear calculation);

- upon passing of the peak value, deflections will rise at the lowering load (figure 3). The secondary bifurcation (wave formation in the plate extreme ribs) will occur at the second buckling load Pbif. $=5880 \mathrm{~kg}$.

Figure 4 shows the deformed state of a stiffened plate. It is obvious that the increasing deflection makes the bending moment bigger in the middle part, and we see not only the developing wave formation in the ribs but also the forced wave formation of the plate itself, which provokes considerable decrease of the bending rigidity.

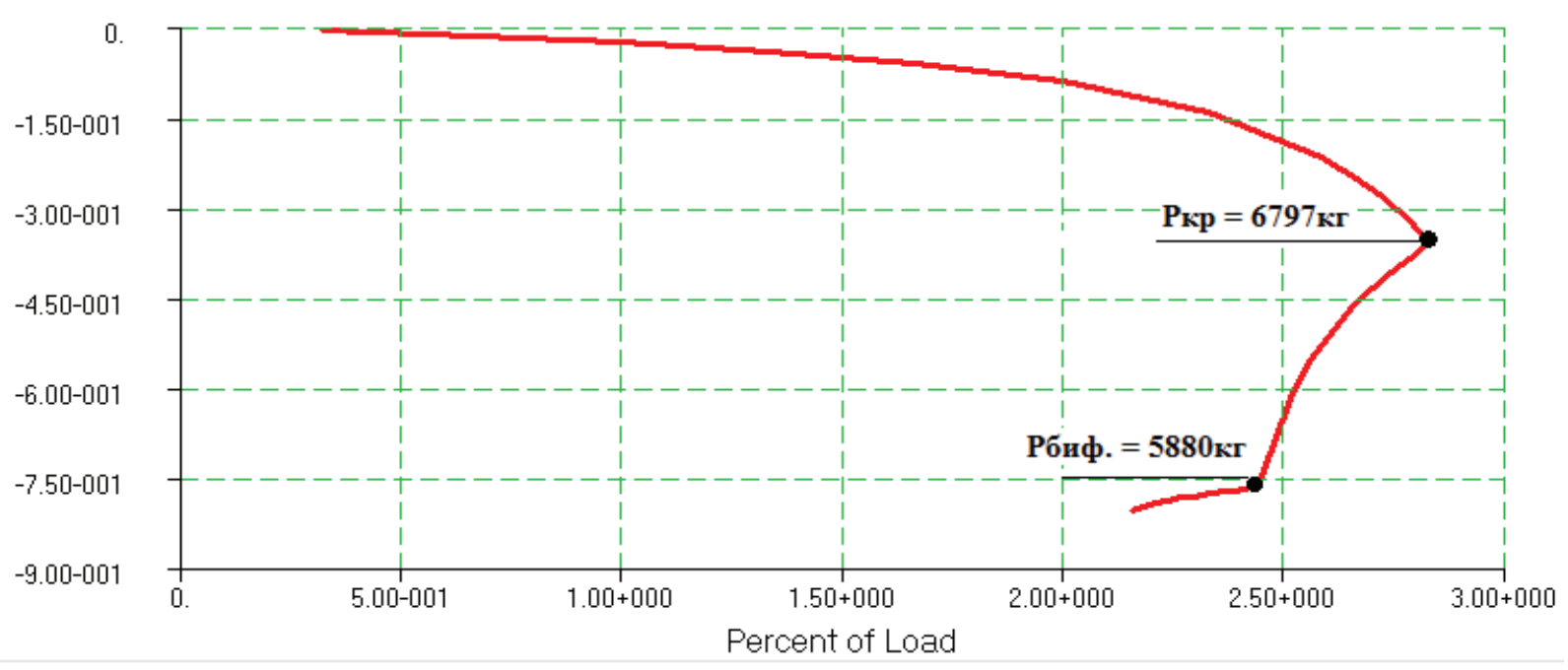

Figure 3. Graph of dependency "deflections vs compressing loads". 


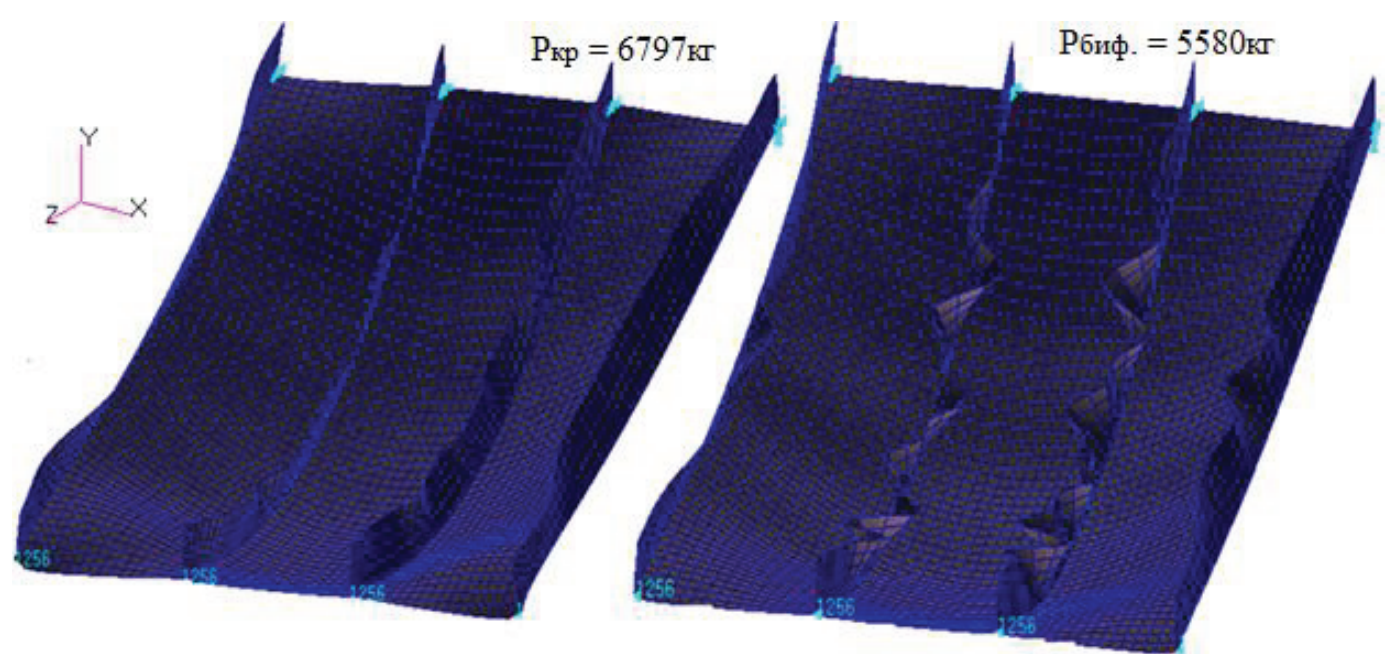

Figure 4. Deformable state of stiffened plate $\delta=0.155 \mathrm{~cm}$ thick.

\section{TWO-FOLD BIFURCATION POINT}

The semi-symmetric two-fold bifurcation point is a special critical point. At an odd number of waves, the symmetry of post-bifurcation paths will remain for wave formation shape of ribs only.

Initial post-bifurcation paths (there may be one or three of them) are plotted in the three-dimensional space on two coordinates $\mathrm{q}_{1}, \mathrm{q}_{2}$, and load parameter $\lambda$.

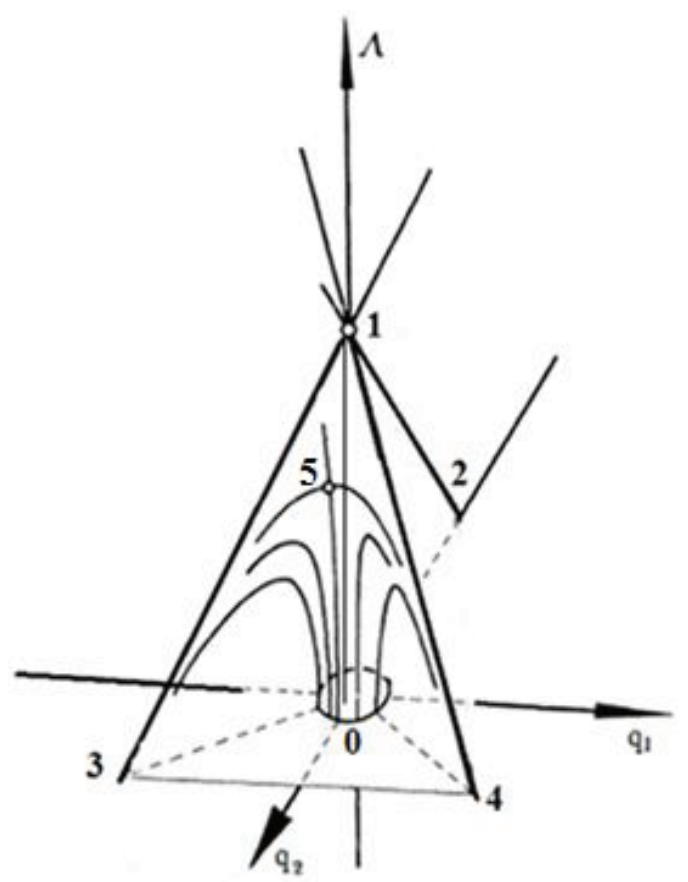

Figure 5. Anticlinal bifurcation point
In figure 5 we use the following notation: $\mathrm{q}_{1}$ - coordinate corresponding to relative amplitudes of wave formation in ribs;

$\mathrm{q}_{2}$ - coordinate corresponding to relative amplitudes of the plate buckling as a Eulerian rod;

$\lambda$ - load parameter $\left(\lambda=\mathrm{P}-\mathrm{P}_{\mathrm{cr}}\right)$

Point 1 - semi-symmetric two-fold bifurcation point;

Right line $0-1$ describes the pure compression pre-critical equilibrium;

Right line $1-2$ is the line of incoherent equilibriums corresponding to the relative amplitude on the form of the stiffened plate buckling a Eulerian rod;

Right lines $1-3$ and $1-4$ are the lines coherent equilibriums coordinates whereof depend both on Eulerian deflection and on amplitude of wave formation in ribs [2];

Consequently, at the two-fold buckling load, the ribs (or plate) buckling failure cannot arise in form of a separate (partial) buckling form (i.e. wave formation at the zero general deflection).

Point 5 is the point of symmetric unstable bifurcation on the Eulerian general deflection curve which occurs at intersection of the "triangle" plane of coherent equilibriums $1-3-4$ by this curve. This point corresponds to the bifurcation point at the peak load $\mathrm{P}_{\mathrm{cr}}=6797 \mathrm{~kg}$ (figure 3).

The catastrophe germ of the elliptic umbilic (the first two terms in expression (1) is generated from uniform cubes for two variables with taking into account the symmetry on the first coordinate 
and absence of symmetry on the second one. In total, the cubic potential for umbilic catastrophes can be presented as follows:

$$
\begin{array}{r}
V\left(q_{1}, q_{2}, \varepsilon_{j}\right)=\frac{1}{6} V_{222}^{\mathrm{\kappa p}} q_{2}^{3}+\frac{1}{2} V_{112}^{\mathrm{\kappa p}} q_{1}^{2} q_{2}+ \\
\frac{1}{2} \lambda\left(V_{11 \lambda}^{\mathrm{\kappa p}} q_{1}^{2}+V_{22 \lambda}^{\mathrm{\kappa p}} q_{2}^{2}\right)+V_{1}^{1 \kappa \mathrm{sp}} \varepsilon_{1} q_{1}+V_{2}^{2 \kappa \mathrm{\kappa}} \varepsilon_{2} q_{2} ;
\end{array}
$$

The lower indexes designate differentiation on appropriate coordinates and on the load parameters. All derivatives are calculated in the bifurcation point (the upper index "кр”).

For an ideal system, at $\varepsilon_{1}=\varepsilon_{2}=0$, equilibrium equations are obtained by setting equal to zero of derivatives of potential (1) on each coordinate:

$$
\begin{array}{r}
V_{112}^{\mathrm{kp}} q_{1} q_{2}+\lambda V_{11 \lambda}^{\mathrm{kp}} q_{1}=0 ; \\
\frac{1}{2} V^{\mathrm{\kappa p}}{ }_{222} q_{2}^{2}+\frac{1}{2} V^{\mathrm{\kappa p}}{ }_{112} q_{1}^{2}+\lambda V_{22 \lambda}^{\mathrm{kp}} q_{2}=0
\end{array}
$$

Let's show that initial post-bifurcation paths of equilibriums are straight lines.

Equilibrium equations (2), (3) may be solved in three variants:

- $\mathrm{q}_{1}=\mathrm{q}_{2}=0$ - initial equilibrium of a non-bent stiffened plate;

- the solution at $\mathrm{q}_{1}=0, \mathrm{q}_{2} \neq 0$ corresponds to the general bending of the plate as a Eulerian rod. Then, from the equilibrium equation (3), taking $\mathrm{q}_{1}=0$, we obtain the equation of non-coherent post-bifurcation straight line of general deflection $1-2$ (figure 5):

$$
q_{2}=\frac{-2 \lambda V_{22 \lambda}^{\mathrm{Kp}}}{V^{\mathrm{kp}} 222} \text { or } \frac{\lambda}{q_{2}}=\frac{V^{\mathrm{Kp}} 222}{2 V_{22 \lambda}^{\mathrm{Kp}}}
$$

- $\mathrm{q}_{2} \neq 0, \mathrm{q}_{1} \neq 0$. Then, expressing $\lambda$ from Equation (2):

$$
\lambda=\frac{-V_{112}^{\mathrm{kp}} q_{2}}{V_{11 \lambda}^{\mathrm{Kp}}}
$$

and substituting it into Equation (3), we obtain:

$\frac{1}{2} V^{\mathrm{Kp}}{ }_{222} q_{2}^{2}+\frac{1}{2} V_{112}^{\mathrm{\kappa p}}-\frac{V_{112}^{\mathrm{Kp}} V_{22 \lambda}^{\mathrm{Kp}} q_{2}^{2}}{V_{11 \lambda}^{\mathrm{Kp}}}=0$

$$
\frac{q_{1}}{q_{2}}= \pm\left(\frac{2 V_{22 \lambda}^{\mathrm{Kp}}}{V_{11 \lambda}^{\mathrm{Kp}}}-\frac{V^{\mathrm{Kp}} 222}{V^{\mathrm{Kp}} 112}\right)^{\frac{1}{2}}
$$

Thus, it is demonstrated that all post-bifurcation equilibrium paths are straight lines. Earlier, similar computations for the homeoclinal bifurcation point were presented in the authors' paper [16], when analyzing interaction of wave formation shape in the plate and general deflection of the plate as a Eulerian rod.

Ratio signs of derivatives under the root sign in Formula (7) are important for determining the type of bifurcation umbilic point. The first ration is always positive here. If ratios $\frac{V_{22 \lambda}^{\mathrm{Kp}}}{V_{11 \lambda}^{\mathrm{kp}}}$ and $\frac{2 V^{\mathrm{Kp}} 222}{V^{\mathrm{Kp}}{ }_{112}}$ possess opposite signs, straight lines of coherent equilibriums 1-3 and 1-4 "fall" in the direction opposite to that of "falling" of the non-coherent post-bifurcation straight line of general deflection $1-2$, and we obtain the anticlinal bifurcation point corresponding to the elliptic umbilic catastrophe. For a stiffened plate, such two-fold bifurcation point may be realized only when deflection of this plate develops in such a way that ribs and additionally loaded with compression stresses from the bending moment arisen.

\section{STUDYING OF INFLUENCE OF INI- TIAL GEOMETRIC IMPERFECTIONS ON BUCKLING LOAD}

To explore the influence of initial imperfections, the authors used eigenforms of buckling failure obtained by means of liner computations. Geometric imperfections were set on the forms of:

- initial wave formation in ribs (wave formation of two extreme ribs, two middle ribs, simultaneous wave formation in four ribs), $\varepsilon_{1}$;

- buckling of the plate as a Eulerian rod, $\varepsilon_{2}$;

- imperfection on two forms $\varepsilon_{1}+\varepsilon_{2}$ and $\sqrt{3} \varepsilon_{1}+\varepsilon_{2}$. Relative amplitudes of imperfections were set in fractions of the plate thickness $(0.1 \delta, 0.2 \delta$, $0.5 \delta, 1 \delta, 2 \delta)$. It is obvious that the provoking factor of wave formation in ribs was the bending moment developing under action of compressive 
forces in the stiffened plate middle part. Upon excluding the initial deflection and using only the shape of wave formation of ribs as the initial imperfection, we obtained the following results:

- buckling failure occurred in the limit point of equilibrium curves of wave formation in ribs;

- initial imperfection in form of wave formation in extreme ribs only provoked local buckling of the plate, and thereafter the secondary bifurcation of wave formation in middle ribs took place; the same effect was observed at setting of imperfections for two middle ribs only;

- it was found that wave formation in middle ribs only decreased bearing capacity of a stiffened plate to a higher extent, as compared to influence of the similar imperfections in extreme ribs.

Table 1 presents values of buckling loads of imperfect plates.

Table 1. Values of buckling loads for a plate with imperfection on the shape of wave

Imperfection value on the shape of wave formation of ribs

formation of ribs

\begin{tabular}{|c|c|c|c|c|c|}
\hline \multicolumn{6}{|c|}{$\begin{array}{l}\text { Imperfection value on the shape of wave formation of ribs } \\
\text { (wave formation of two middle ribs) }\end{array}$} \\
\hline 0 & $0.1 \delta$ & $0.2 \delta$ & $0.5 \delta$ & $1 \delta$ & $2 \delta$ \\
\hline \multicolumn{6}{|c|}{ Buckling load, kg } \\
\hline 6797 & 6327 & 6009 & 5469 & 4874 & 4656 \\
\hline \multicolumn{6}{|c|}{$\begin{array}{l}\text { Imperfection value on the shape of wave formation of ribs } \\
\text { (wave formation of two extreme ribs) }\end{array}$} \\
\hline 0 & $0.1 \delta$ & $0.2 \delta$ & $0.5 \delta$ & $1 \delta$ & $2 \delta$ \\
\hline \multicolumn{6}{|c|}{ Buckling load, kg } \\
\hline 6797 & 6644 & 6508 & 6238 & 5812 & 5130 \\
\hline
\end{tabular}

The decrease of the stiffened plate-buckling load from imperfection on the shape of wave formation of ribs (wave formation of two extreme ribs) was $24.52 \%$, and that from imperfection of wave formation of two middle ribs was $31.5 \%$. In figure 6 we can see curves of decrease of critical values for a plate with imperfection on the shape of wave formation of ribs.

The next step in the research is aimed at studying of curves of equilibrium states of imperfect stiffened plates and at plotting of the bifurcation surface.

In figure 7, we can see curves of equilibrium states of the plate with various imperfection amplitudes on buckling form as Eulerian rod.

The initial deflection direction was chosen in such a way that the ribs would occur in the compressed zone (with convex section downward). Buckling failure occurred in the limit point of the curve of equilibrium on deflections.
Depending on the initial imperfection amplitude, bifurcation of wave formation of ribs arose either later than the limit point (in case of small amplitudes $0.1 \delta, 0.2 \delta, 05 \delta$ ), or in the limit point (when imperfection amplitude is equal to $1 \delta$ ), or preceded to it, as in the case of setting of the imperfection with amplitude $2 \delta$ (inflection on the curve of equilibrium states, figure 7).

The decrease of the buckling load in case of setting the initial imperfection on the general deflection shape and amplitude $2 \delta$ was equal to $32.78 \%$. Turning to the bifurcation diagram (figure 5) one can state that all post-bifurcation paths of imperfect equilibriums achieve their peak loads in limit points; further on, they become instable and asymptotically approach coherent equilibriums 1-2 straight line. 

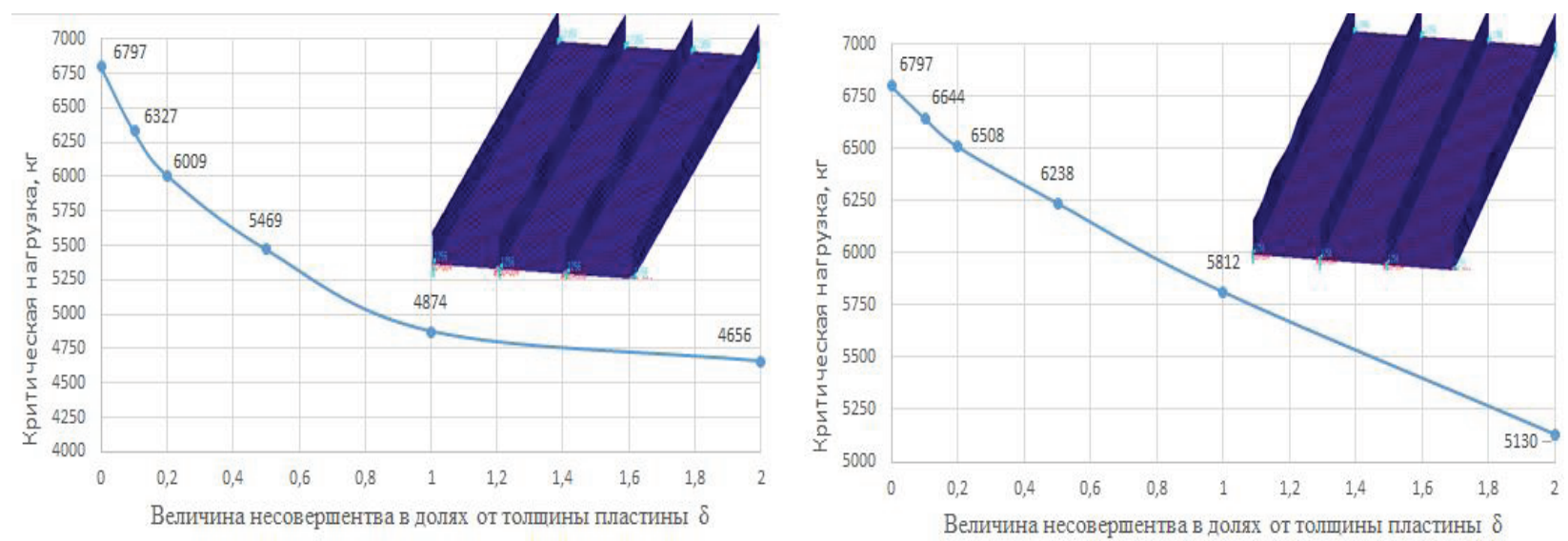

Figure 6. Curves of decrease of stiffened plate buckling loads from imperfection of wave formation of ribs $(0.1 \delta, 0.2 \delta, 0.5 \delta, 1 \delta, 2 \delta)$.

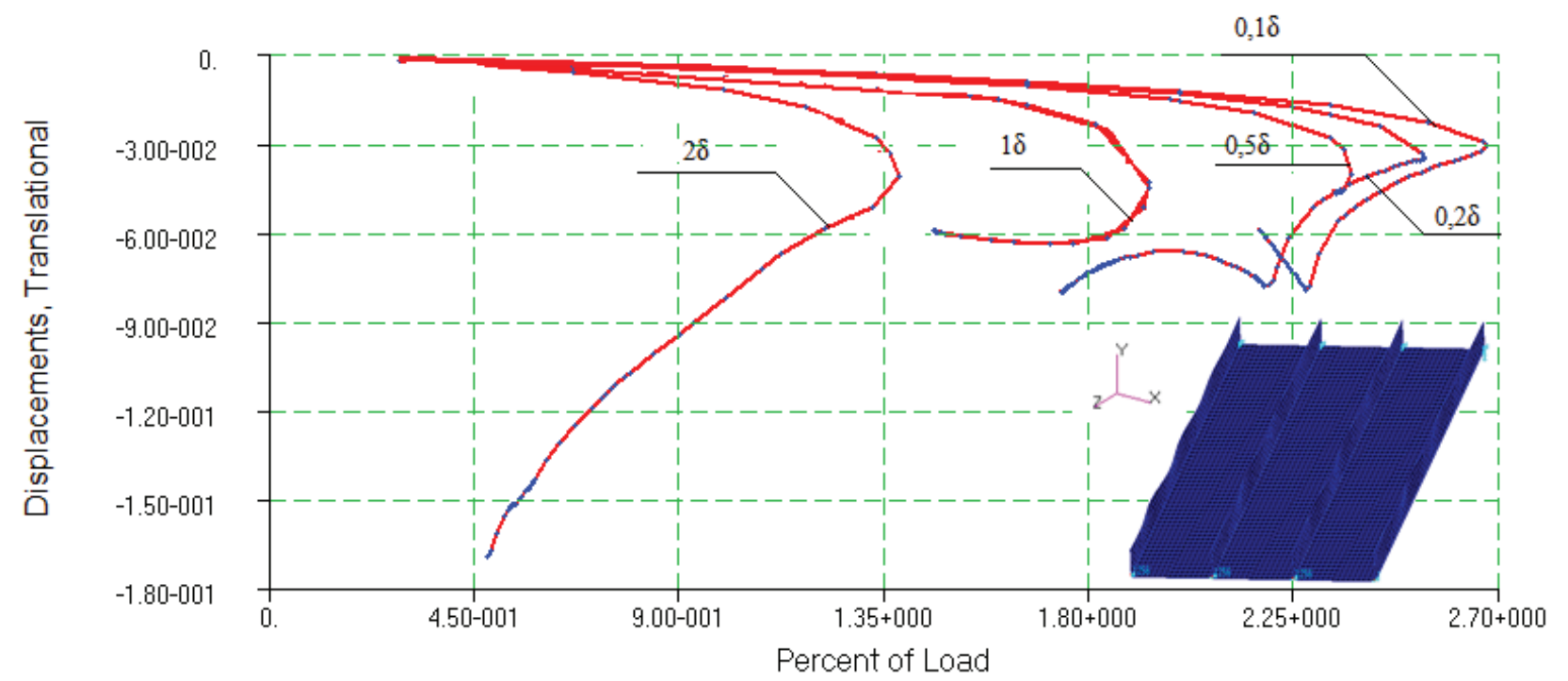

Figure 7. Curves of equilibrium states of stiffened plate with imperfection on buckling form as Eulerian $\operatorname{rod}(0.1 \delta, 0.2 \delta, 0.5 \delta, 1 \delta, 2 \delta)$.

In figure 8 we can see curves equilibrium states of a stiffened plate with imperfection on the form of wave formation in ribs (simultaneous wave formation in four ribs).

Analysis of results showed that buckling failure occurs in limit points of the curves of ribs wave formation. The maximum decrease of the buckling load from imperfection on this shape with amplitude $2 \delta$ was equal to $51 \%$. All post-bifurcation paths of imperfect equilibriums achieved their limit points and further on they asymptotically approached straight lines of coherent equilibriums 1-3 and 1-4 (figure 5).

Basing on the obtained results, the bifurcation surface "front part" was plotted close in the shape to a relevant part of the elliptical umbilic bifurcation surface demonstrated in the monograph by B. Gilmour, page 277 [15]. Table 2 presents values of buckling loads for stiffened plates with various types and amplitudes of initial imperfections. 


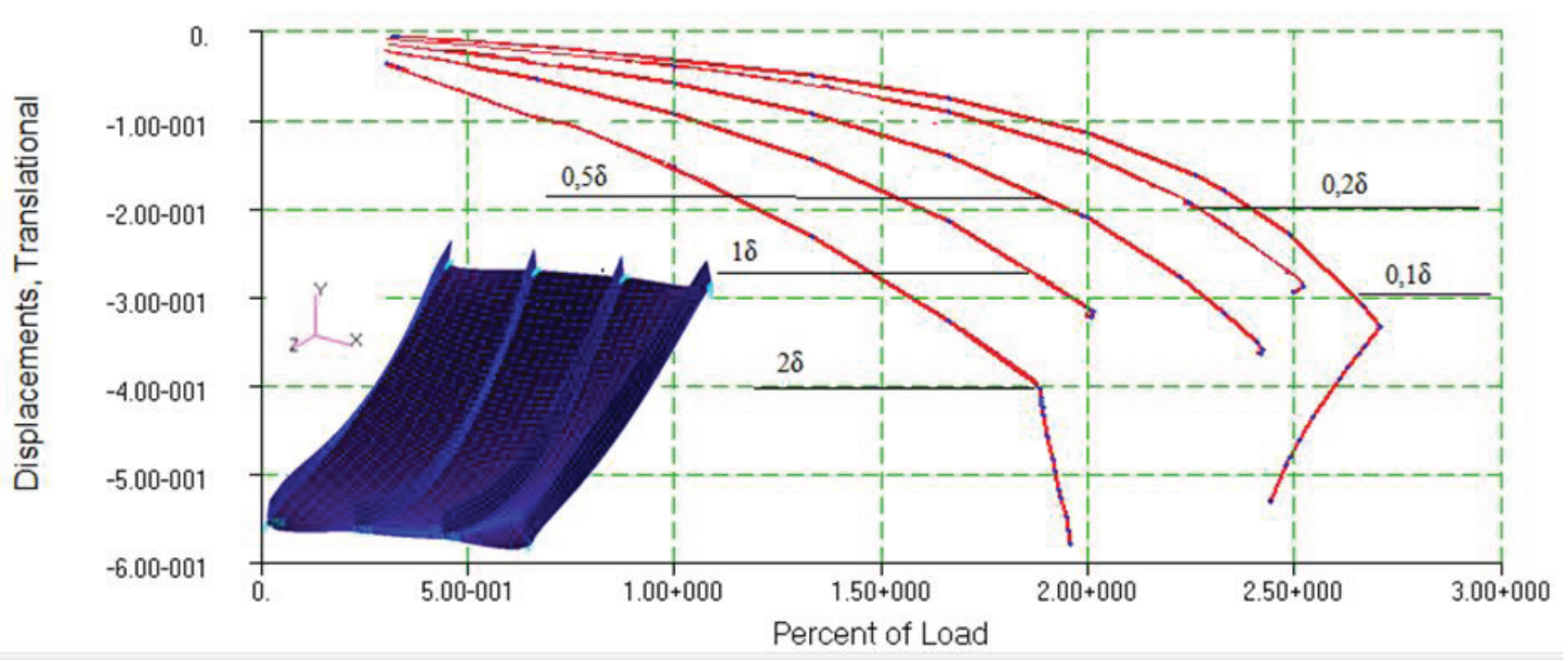

Figure 8. Curves of equilibrium states of stiffened plate with imperfection on the form of simultaneous wave formation in four ribs (amplitudes $0.1 \delta, 0.2 \delta, 0.5 \delta, 1 \delta, 2 \delta$ ).

Table 2. Data for plotting of bifurcation surface

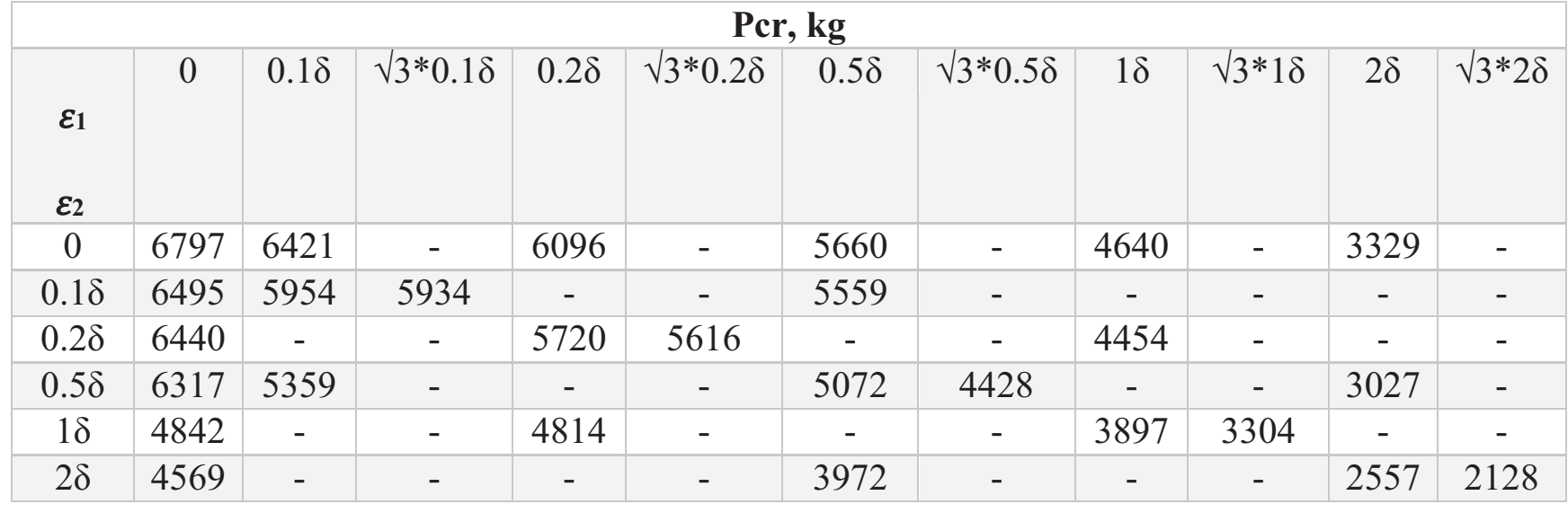

\section{CONCLUSIONS}

It is demonstrated that the peak decrease of the buckling load of a stiffened plate was recorded at setting of the joint imperfection on two forms $\sqrt{3} \varepsilon_{1}+\varepsilon_{2}$ with amplitude $2 \delta+\sqrt{3} * 2 \delta$ and was equal to $68.7 \%$. Setting of the joint imperfection on two forms $\varepsilon_{1}+\varepsilon_{2}$ with amplitude $2 \delta$ decreased the bearing capacity by $62 \%$. The obtained results of the study of initial imperfections influence confirm D. Ho's theorems ([14], 1974), according whereto, for two-fold bifurcation points with cubic potential, the buckling load peak decrease is caused by imperfections possessing the shape of the most steeply falling post-bifurcation equilibriums. Within this task, most steeply falling are straight lines of coherent equilibriums 1 2 and $1-3$ (figure 5).

Let's note also that our results confirm certain conclusions of A.I. Manevich [12] about strong response of buckling loads to initial imperfections in the plate ribs. It was found that the provoking factor of wave formation in ribs was additional compression generated by the bending moment in the stiffened plate middle part, due to development of general deflection in a certain direction. 


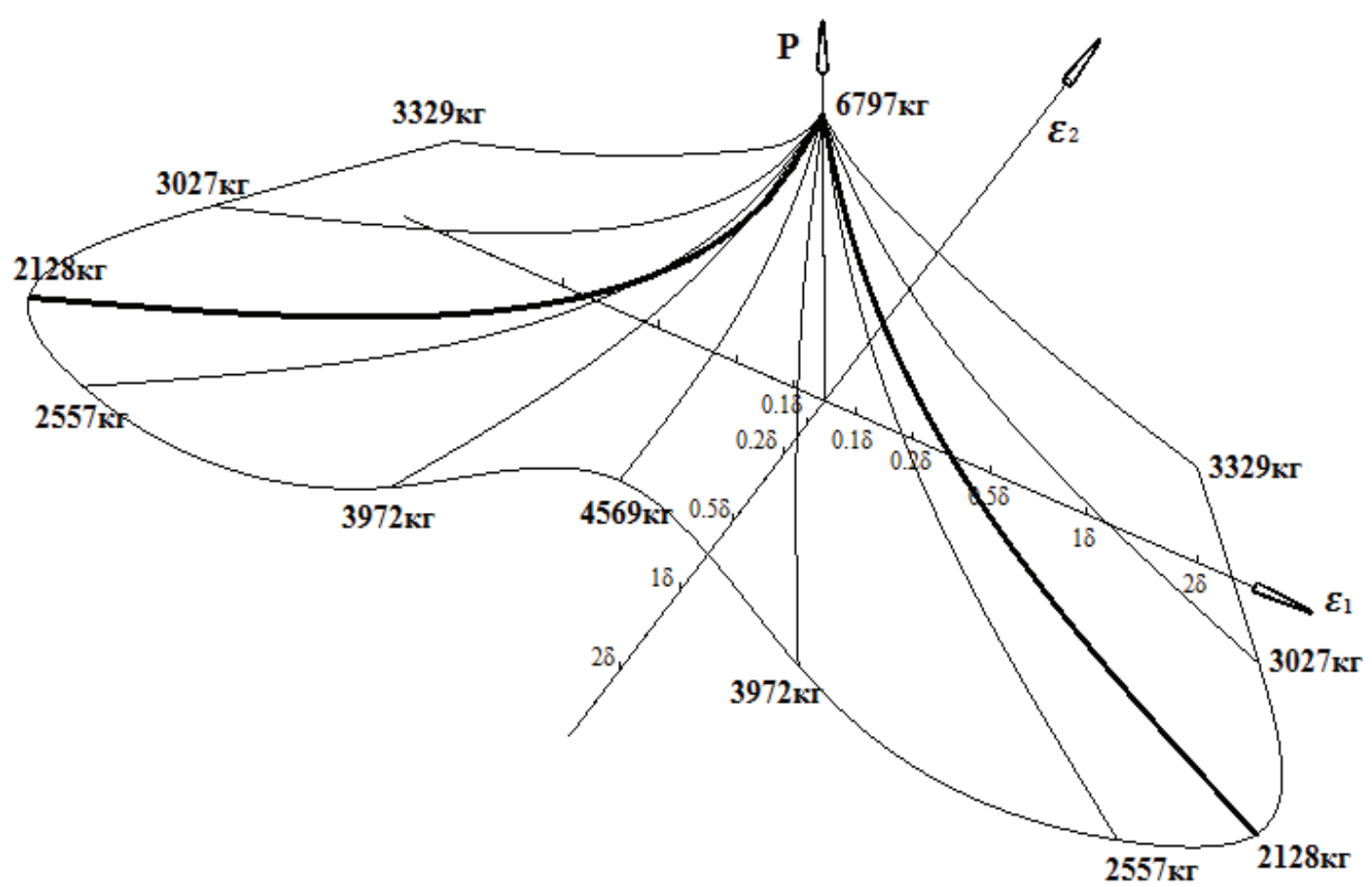

Figure 9. Bifurcation surface.

\section{REFERENCES}

1. Fok W.C., Rhodes J., Walker A.C. Local buckling of outstands in stiffened plates. // Aeronaut Q 27, 1976, pp. 277-291.

2. Hunt G.W. Imperfections and near-coincidence for semi-symmetric bifurcations. // New York in Conference on Bifurcation Theory and Applications in Scientific Disciplines Ann. N.Y. Academy of Science 316, 1977, pp. 572-589.

3. Hunt G.W. An algorithm for the nonlinear analysis of compound bifurcation. London Phil. Trans. R. Soc. Lond. A 1981, 1981, 300 pages.

4. Hunt G.W. Imperfection-sensitivity of semi-symmetric branching (Proc. R. Soc. Lond. A 1977, 1977, Volume 357, pp. 193211.

5. Koiter W.T., Pignataro M.A. General Theory for the interaction between Local and Overall Buckling of Stiffened Panels. Delft WTHD Report 83, 1976, pp. 179-222.

6. Maquoi R., Massonnet C. Interaction between local plate buckling and overall buckling in thin-walled compression members. //
New York Harvard University Theories and experiments in Proceedings of the IUTAM International Symposium on Buckling of Structures, 1976, pp. 365-382.

7. Roorda J. The buckling behavior of imperfect structural systems. London Department of Civil Engineering, University College, 1965, pp. 267-280.

8. Thompson J.M.T., Tan J.K.Y., Lim K.C. On the Topological Classification of Postbuckling Phenomena (Journal of Structural Mechanics Volume, 1978, Volume 64, pp. 383-414.

9. Thompson J.M.T., Gaspar Z. A buckling model for the set of umbilic catastrophes. // Mathematical Proceedings of the Cambridge Philosophical Society, 1977, Volume 82, Issue 03, pp. 497-507.

10. Tvergaard $\mathbf{V}$ Imperfection sensitivity of a wide integrally stiffened panel under compression. // Int. J. Solids Sructures, 1973, Volume 9, pp. 177-192.

11. Van Der Neut A. The interaction of local buckling and column failure of imperfect thin-walled compression members. Delft 
Technological University Report VTH 149, 1968, pp. 391-398.

12. Van Der Neut A. Mode interaction with a stiffened panel. // Harvard Proc. IUTAM Symp., Buckling of structures, 1974, pp. 117-132.

13. Van Der Neut A., Majer J. The interaction of local buckling and column failure of imperfect thin-walled compression members. Delf University of Technology, Department of Aeronautic engineering Report VTH 160, 1970, pp. 6-18.

14. Ho D. Buckling load of non-linear systems with multiple eigenvalues. // Int. J. Solids Structures, Pergamon Press. Printed in Gt. Britain, 1974, pp. 1315-1330.

15. Gilmour B. Prikladnaja teorija katastrof [Applicable theory of catastrophes]. Volume 1. Moscow, MIR, 1984, pp. 268-277 (in Russian)

16. Manuylov G.A., Kositsyn S.B., Grudtsyna I.E. Chislennyj analiz kriticheskogo ravnovesija gibkoj podkreplennoj plastiny s uchetom vlijanija nachal'nyh geometricheskih nesovershenstv [Numerical Analysis Critical Equilibrium Of Flexible Supported Plate With Allowance For Influence Initial Geometrical Imperfections]. // Structural Mechanics And Analysis Of Constructions, 2020, No. 1, pp. 3036 (in Russian).

17. Manevich A.I. K teorii svjazannoj poteri ustojchivosti podkreplen-nyh tonkostennyh konstrukcij [On the theory of coupled loss of stability in stiffened thin-walled structures]. // Applicable mathematics and mechanics, 1982, No. 2, pp. 337-345 (in Russian).

18. Manevich A.I. Vzaimodejstvie form poteri ustojchivosti szhatoj podkreplennoj paneli [Interaction of forms of buckling failure of compressed stiffened panel]. // Structural Mechanics And Analysis Of Constructions, 1981, No. 5, pp. 24-29 (in Russian).

19. Manevich A.I. Nelinejnaja teorija ustojchivosti podkreplennyh plastin i obolochek s uchetom vzaimodejstvija form vypuchivanija [Nonlinear theory of stability of stiffened plates and shells, with taking into account of buckling forms interaction].
Dissertation abstract for procuring of the academic degree of Doctor of Engineering, Leningrad, 1988, 33 pages (in Russian).

20. Thompson J.M.T. Neustojchivosti i katastrofy $\mathrm{v}$ nauke i tehnike [Buckling and catastrophes in science and engineering]. Moscow, MIR, 1985, pp. 21-37 (in Russian).

\section{СПИСОК ЛИТЕРАТУРЫ}

1. Fok W.C., Rhodes J., Walker A.C. Local buckling of outstands in stiffened plates. // Aeronaut Q 27, 1976, pp. 277-291.

2. Hunt G.W. Imperfections and near-coincidence for semi-symmetric bifurcations. // New York in Conference on Bifurcation Theory and Applications in Scientific Disciplines Ann. N.Y. Academy of Science 316, 1977, pp. 572-589.

3. Hunt G.W. An algorithm for the nonlinear analysis of compound bifurcation. London Phil. Trans. R. Soc. Lond. A 1981, 1981, 300 pages.

4. Hunt G.W. Imperfection-sensitivity of semi-symmetric branching (Proc. R. Soc. Lond. A 1977, 1977, Volume 357, pp. 193211.

5. Koiter W.T., Pignataro M.A. General Theory for the interaction between Local and Overall Buckling of Stiffened Panels. Delft WTHD Report 83, 1976, pp. 179-222.

6. Maquoi R., Massonnet C. Interaction between local plate buckling and overall buckling in thin-walled compression members. // New York Harvard University Theories and experiments in Proceedings of the IUTAM International Symposium on Buckling of Structures, 1976, pp. 365-382.

7. Roorda J. The buckling behavior of imperfect structural systems. London Department of Civil Engineering, University College, 1965, pp. 267-280.

8. Thompson J.M.T., Tan J.K.Y., Lim K.C. On the Topological Classification of Postbuckling Phenomena (Journal of Structural Mechanics Volume, 1978, Volume 64, pp. 383-414. 
9. Thompson J.M.T., Gaspar Z. A buckling model for the set of umbilic catastrophes. // Mathematical Proceedings of the Cambridge Philosophical Society, 1977, Volume 82, Issue 03, pp. 497-507.

10. Tvergaard V Imperfection sensitivity of a wide integrally stiffened panel under compression. // Int. J. Solids Sructures, 1973, Volume 9, pp. 177-192.

11. Van Der Neut A. The interaction of local buckling and column failure of imperfect thin-walled compression members. Delft Technological University Report VTH 149, 1968, pp. 391-398.

12. Van Der Neut A. Mode interaction with a stiffened panel. // Harvard Proc. IUTAM Symp., Buckling of structures, 1974, pp. 117-132.

13. Van Der Neut A., Majer J. The interaction of local buckling and column failure of imperfect thin-walled compression members. Delf University of Technology, Department of Aeronautic engineering Report VTH 160, 1970, pp. 6-18.

14. Ho D. Buckling load of non-linear systems with multiple eigenvalues. // Int. J. Solids Structures, Pergamon Press. Printed in Gt. Britain, 1974, pp. 1315-1330.

15. Гилмор Р. Прикладная теория катастроф. Том 1. - М.: Мир, 1984, с. 268-277.

16. Мануйлов Г.А., Косицын С.Б., Грудцына И.Е. Численный анализ критического равновесия гибкой подкрепленной пластины с учетом влияния начальных геометрических несовершенств. // Строительная механика и расчет сооружений, 2020, №1, с. 30-36.

17. Маневич А.И. К теории связанной потери устойчивости подкрепленных тонкостенных конструкций. // Прикладная математика и механика, 1982, №2, с. 337345.

18. Маневич А.И. Взаимодействие форм потери устойчивости сжатой подкрепленной панели. // Строительная механика и расчет сооружений, 1981, №5, с. 24-29.
19. Маневич А.И. Нелинейная теория устойчивости подкрепленных пластин и оболочек с учетом взаимодействия форм выпучивания. Автореферат диссертации на соискание ученой степени доктора технических наук по специальности 01.02.04 «Механика деформируемого твердого тела». - Л.: Ленинградский политехнический институт имени М.И. Калинина, 1988. $-33 \mathrm{c}$.

20. Томпсон Дж.М.Т. Неустойчивости и катастрофы в науке и технике. - М.: Мир, 1985 , c. 21-37.

Gaik A. Manuylov, Ph.D.; Associate Professor, Department of Structural Mechanics, Moscow State University of Railway Engineering (MIIT); 127994, Russia, Moscow, 9b9 Obrazcova Street; phone/fax +7(499)972-49-81.

Sergey B. Kosytsyn, Advisor of the Russian Academy of Architecture and Construction Sciences (RAACS), Professor, Dr.Sc.; Head of Department of Theoretical Mechanics, Russian University of Transport (MIIT); 9b9, Obrazcova Street, Moscow, 127994, Russia;

phone/fax: +7(499) 978-16-73;

E-mail: kositsyn-s@yandex.ru, kositsyn-s@mail.ru.

Irina E. Grudtsyna, PhD student of Department of Theoretical Mechanics, Russian University of Transport (MIIT); 9b9, Obrazcova Street, Moscow, 127994, Russia; Phone/fax: +7(915) 351-95-09;

E-mail: Grudtsyna_ira90@mail.ru.

Мануйлов Гайк Александрович, кандидат технических наук, доцент, доцент кафедры «Строительная механика» Российского Университета Транспорта (РУТ (МИИТ)); 127994, г. Москва, ул. Образцова, 9; тел./факс +7(499) 972-49-81.

Косицын Сергей Борисович, доктор технических наук, профессор, заведующий кафедрой «Теоретическая механика» Российского Университета Транспорта (РУТ (МИИТ)); 127994, Россия, г. Москва, ул. Образцова, 9; тел./факс +7(499) 978-16-73;

E-mail: kositsyn-s@yandex.ru,kositsyn-s@mail.ru.

Грудцына Ирина Евгеньевна, ассистент кафедры «Теоретическая механика» Российского Университета Транспорта (РУТ (МИИТ)); 127994, Россия, г. Москва, ул. Образцова, 15; тел./факс +7(915) 351-95-09;

E-mail: Grudtsyna_ira90@mail.ru. 